Korevaar, J., Donker, G. Taakverschuiving van huisarts naar verpleegkundige. Huisarts \& Wetenschap: 2019, 11

$\begin{array}{lll}\text { Postprint version } & : & 1.0 \\ \text { Journal website } & : & \text { https://www.henw.org/artikelen/taakverschuiving-van-huisarts-naar- } \\ & \text { verpleegkundige }\end{array}$

Pubmed link

DOI

: $10.1007 / \mathrm{s} 12445-019-0269-6$

This is a Nivel certified Post Print, more info at nivel.nl

\title{
Taakverschuiving van huisarts naar verpleegkundige
}

\author{
Joke Korevaar, Gé Donker ${ }^{1}$
}

\begin{abstract}
De werkdruk van huisartsen is hoog en wordt nog hoger door veroudering van de bevolking en een dreigend tekort aan huisartsen. Een oplossing is om verpleegkundigen taken te laten overnemen van de huisarts. De auteurs van een cochranereview bekeken wat patiënten, huisartsen en verpleegkundigen hiervan vinden en welke ervaring ze hiermee hebben. Daaruit blijkt dat goede scholing, goede verwijsmogelijkheden, duidelijke taakverdeling en goede begeleiding randvoorwaarden voor slagen zijn.
\end{abstract}

De auteurs zochten naar kwalitatief onderzoek waarin meningen werden gepresenteerd over en randvoorwaarden voor het verschuiven van taken van de huisarts naar een verpleegkundige ${ }^{1}$. Ze includeerden 66 onderzoeken.

Patiënten wisten weinig over de rol van de verpleegkundige in de eerste lijn en hadden verschillende opvattingen over welk taken door verpleegkundigen kunnen worden uitgevoerd. Ze hadden voorkeur voor de huisarts bij medische taken. Bij preventieve of follow-up zorg accepteerden zij verpleegkundigen. Ook de huisartsen en verpleegkundigen gaven deze voorkeur aan. Zowel huisartsen als verpleegkundigen zagen taakverschuiving als een manier om de toegang tot en de continuïteit van de zorg te verbeteren.

Verpleegkundigen denken dat een nauwe samenwerking met en vertrouwen van de huisarts belangrijk is om hun bredere rol, vorm en status te geven. Zij vonden de samenwerking met de huisarts echter soms moeilijk. Verder wilden zij graag goede scholing voor deze nieuwe taken hebben en denken zij dat taakuitbreiding leidt tot meer vaardigheden, motivatie, zelfstandigheid en verbetering van de kwaliteit van zorg voor hun patiënten. Ook het vooruitzicht op een hoger salaris werkte motiverend. Huisartsen waardeerden de taakverschuiving zodra hun werklast erdoor afnam. Zowel huisartsen als verpleegkundigen benadrukten het belang van voldoende ondersteunend personeel, goede verwijsmogelijkheden, duidelijke taakverdeling en een goede begeleiding .

De auteurs gebruikten de GRADE-CERQual-methode om de betrouwbaarheid van de gevonden resultaten te bepalen, deze was voor de meeste resultaten matig. De methodologisch beperkingen werden bepaald met de 'modified Critical Appraisal Skills Programme' tool. De helft van de onderzoeken had weinig beperkingen, de andere helft matige tot ernstige beperkingen. In Nederland is taakherschikking naar de praktijkondersteuner huisartsenzorg (poh) voor geprotocolleerde zorg voor chronische aandoeningen 15 jaar geleden al ingezet en sindsdien sterk gegroeid. Zo waren er in 2011 circa 1900 fte poh's werkzaam in de huisartsenpraktijken. In 2016 was hun aantal meer dan verdubbeld (4300 fte) en dit zal gezien de verwachte toename in het aantal 
Korevaar, J., Donker, G. Taakverschuiving van huisarts naar verpleegkundige. Huisarts \& Wetenschap: 2019, 11

patiënten met een chronische aandoening alleen maar toenemen.2 Daarnaast is er, met het oog op de veranderende zorgvraag, in 2018 een nieuw competentieprofiel voor de praktijkverpleegkundige huisartsenzorg (pvh) vastgesteld. Daarmee kan de groeiende groep patiënten worden bediend met hoogcomplexe aandoeningen zoals kwetsbare, thuiswonende ouderen en patiënten met multimorbiditeit met integrale en protocoloverstijgend handelen. Voor de huidige, in ketenzorg getrainde poh's (diabetes mellitus, COPD en CVRM) is deze benadering niet gemakkelijk in te vullen. De zorg die de pvh kan leveren is dan ook een aanvulling op die van de poh. Toevoegen van een pvh aan het team van de huisartsenvoorziening is een keuze van de huisartsenpraktijk, afhankelijk van praktijkgrootte, de samenstelling van de patiëntenpopulatie en de situatie op de arbeidsmarkt.

\section{Literatuur}

1. Karimi-Shahanjarini A, Shakibazadeh E, Rashidian A, Hajimiri K, Glenton C, Noyes J, et al. Barriers and facilitators to the implementation of doctor-nurse substitution strategies in primary care: a qualitative evidence synthesis. Cochrane Database Syst Rev 2019;4:CD010412.

2. Van Hassel D, Batenburg R, Van der Velden L. Praktijkondersteuners ( $\mathrm{POH}^{\prime} \mathrm{s}$ ) in beeld. Aantallen, kenmerken en geografische spreiding in Nederland. Utrecht: NIVEL, 2016.

Dit is een PEARL, bruikbare wetenschap voor de werkvloer op basis van de Cochrane Database of Systematic Reviews. 